\title{
Observații critice în legătură cu modificările aduse art. 352 C.pen. în contextul pandemiei COVID-19
}

\author{
Asist. univ. dr. Dragoṣ Pârgaru \\ Facultatea de Drept, Universitatea din București
}

Rezumat: Având în vedere împrejurările generate de pandemia COVID-19, legiuitorul penal român a operat modificări importante asupra incriminării uneia dintre faptele antisociale cele mai periculoase în contextul dat, zădărnicirea combaterii bolilor. După o introducere ce are rolul așezării în context a discuției, procedăm la analiza critică a diferitelor variante ale infracțiunii. Articolul urmărește să scoată în evidență, în principal, neconcordanțele și potențialele efecte negative ale modificărilor aduse textului incriminator. În final, luând în considerare toate observațiile, formulăm o propunere de lege ferenda concretă, elaborând un potențial text viitor al art. 352 C.pen.

Cuvinte-cheie: zădărnicirea combaterii bolilor, pandemia COVID-19, boală infectocontagioasă, carantină.

\section{Critical review of art. 352 of the Criminal Code amendments in the context of the COVID- 19 pandemic}

Abstract: Taking into account the situation generated by the COVID-19 pandemic, the Romanian penal legislator relevantly amended the legal characterisation of one of the most dangerous antisocial conducts in such context, the offence of "frustration of disease control". Following an introduction which has the goal to contextualize, we proceed with a review of the different versions of the offence. The article intends to emphasise, mainly, the incongruities and potential negative effects of the implemented amendments. Lastly, noting all observations, we draw a de lege ferenda proposal, drafting a potential future characterisation of the offence provided in art. 352 of the Criminal Code.

Key words: frustration of disease control, COVID-19 pandemic, infecto-contagious disease, quarantine.

La data de 20.03.2020, în contextul pandemiei COVID-19, a fost publicată în Monitorul Oficial Ordonanţa de urgență a Guvernului nr. 28/2020 pentru modificarea și completarea Legii nr. 286/2009 privind Codul Penal. Legiuitorul delegat a răspuns astfel unor solicitări din partea societății pentru sancționarea mai gravă a unor fapte grave și iresponsabile în contextul răspândirii 
noului coronavirus. Chiar anterior ședinței de guvern în care s-a adoptat ordonanța de urgență anterior amintită, de exemplu, a circulat în spațiul public o propunere de modificare a textului art. 352 Cod penal (,zădărnicirea combaterii bolilor”) formulată de Asociația Mișcarea pentru Apărarea Statutului Procurorilor.

Prezentul articol își propune să analizeze critic și rațional modificările legislative aduse art. 352 C.pen. ${ }^{1}$, încercând să scoată în evidență potențiale viitoare probleme ce se vor naște din modul de redactare a textului incriminator, astfel cum a fost modificat prin O.U.G. nr. 28/2020. Prin comparație cu alte materiale doctrinare, prezenta opinie apare cu o oarecare întârziere, deși redactarea articolului a început chiar anterior Ordonanței de urgență a Guvernului. ${ }^{2}$ Însă, constatând caracterul spinos al unor discuții, am preferat să reflectăm o perioadă mai lungă asupra problematicii, desigur, neavând nici la acest moment pretenția că am reușit să deslușim în integralitate voința legiuitorului.

Introductiv, anterior analizei în detaliu a textului de lege, apreciem că se impune să punctăm trei motive generale pentru care se impune critica modificărilor și, poate, o reacție nouă, „de corecție”, din partea legiuitorului.

În primul rând, prin aplicarea legii penale mai favorabile, noua formă a textelor de lege nu va putea fi aplicată faptelor deja săvârșite la momentul intrării în vigoare a O.U.G. nr. 28/2020. Așadar, persoane care până la acel moment, de exemplu, au încălcat starea de carantină ori de izolare la domiciliu vor răspunde penal, dacă se va impune răspunderea penală, potrivit Codului penal, în forma anterioară datei de 20.03.2020. Astfel, o potențială reacție exagerată a legiuitorului se dovedește și inutilă în raport de faptele deja săvârșite.

În al doilea rând, deși pentru prezent există posibilitatea ca noile reglementări să joace un rol preventiv general, există toate premisele ca noi încălcări să mai existe. Or, dacă vor exista asemenea încălcări și, potrivit speranței tuturor, criza epidemiologică se va sfârși într-un interval rezonabil de timp, respectivele cauze penale își vor vedea desfășurarea principală în vremuri mai liniștite, mai lipsite de emoție. În măsura în care se vor constata, de exemplu, probleme de constituționalitate ale noilor texte de lege, dezideratul sancționării aspre a celor care nu respectă în prezent măsurile autorităților se poate dovedi o fata morgana.

În al treilea rând, credem că legea penală nu trebuie să fie construită pentru o situație de o săptămână, o lună sau un an. Legea penală trebuie să transcendă situații particulare și să dețină caracteristicile care să o facă insensibilă la trecerea timpului (evident, în limita posibilului, nefiind

\footnotetext{
${ }^{1}$ Exprimându-ne speranța că într-un articol viitor vom analiza și celelalte modificări ale legislației penale, realizate prin aceeași Ordonanță de urgență a Guvernului.

${ }^{2}$ Respectiv, inițial, ca o critică la o propunere de modificare formulată de Asociația Mișcarea pentru Apărarea Statului Procurorilor.
} 
vorba despre o neadaptabilitate la evoluția societăţii). Oare aceste modificări vor mai fi oportune într-o nouă criză de natură medicală, dar având o cu totul altă cauză? Oare aceste modificări vor mai fi actuale într-o lume fără coronavirus?

$A b$ initio, dorim să subliniem că nu suntem, nicidecum, susținători ai tezei conform căreia nu erau necesare modificări ale Codului penal. Dimpotrivă, credem cu tărie că textul art. 352 Cod penal, în forma anterioară modificărilor, era inadaptat, insuficient atât din punctul de vedere al variantelor de incriminare, cât și din punctul de vedere al pedepselor, și incapabil să asigure funcția preventivă. Pe de altă parte, oare dacă art. 352 Cod penal ar fi prevăzut încă dinaintea crizei epidemiologice actuale pedepse de aproximativ 10-15 ani am fi avut mai puține persoane iresponsabile? Câți dintre juriști - nu mai vorbim, evident, despre non-juriști - cunoșteau anterior acestei perioade conținutul (sau chiar existența) infracțiunii prevăzute la art. 352 Cod penal?

Există un aparent consens asupra faptului că forma infracțiunii de zădărnicire a combaterii bolilor anterioară datei de 20.03.2020 nu asigura o protecție suficientă și, mai ales, nu oferea prevenția generală necesară prin raportare la gravitatea situațiilor care ar impune aplicarea textului de incriminare. Fără a încerca să justificăm caracterul lacunar sau insuficient al fostei reglementări, nu putem, totuşi, să nu observăm că vechiul legiuitor a fost în situația de a reglementa în materie de criză epidemiologică fără a simți ,,pe propria piele" o criză epidemiologică de natura celei prezente.

În plus, cine și-ar fi imaginat în urma nu cu 5-10 ani, ci în urmă cu 4-5 luni că vom ajunge în situația în care pericolul răspândirii comunitare a unui virus letal să apară prin simpla atingere a unui coș de cumpărături, prin apăsarea butonului liftului, prin transmiterea bancnotelor? Mai credem și că vechiul legiuitor penal a avut în vedere art. 352 C.pen. ca o normă care să completeze cadrul legal existent. Credem că legiuitorul nu a avut în vedere acest text de lege ca unul care să înlocuiască, în cazul producerii unor urmări grave, eventuale încadrări juridice în infracțiunile de omor, vătămare corporală, loviri sau vătămări cauzatoare de moarte sau ucidere din culpă.

În continuare, vom proceda la analiza fiecărei variante de incriminare a faptei, nepropunându-ne un examen exhaustiv, respectiv de evidențiere a elementelor de tipicitate, ci, în principal, evidențierea eventualelor probleme de interpretare și viitoare aplicare a textelor de lege.

\section{Art. 352, alin. 1 C.pen. - varianta tip a infracțiunii („,nerespectarea măsurilor de carantină sau de spitalizare dispuse pentru prevenirea sau combaterea bolilor infectocontagioase").}

Una dintre principalele modificări ale textului de lege este reprezentată de transformarea variantei tip dintr-o infracțiune de rezultat într-o infracțiune de pericol abstract. Totuși, pentru a compensa 
o asemenea lărgire a spectrului în privința urmării imediate, legiuitorul a introdus limitări în ceea ce privește situația premisă (necesitatea preexistenței unor măsuri de carantină sau spitalizare).

Deja la acest punct constatăm existența unei prime probleme, respectiv sensul noțiunilor de carantină și spitalizare. Carantina este definită la alin. 9 al art. 352 ca reprezentând ,restricția activităților și separarea de alte persoane, în spații special amenajate, a persoanelor bolnave sau care sunt suspecte de a fi bolnave, intr-o manieră care să prevină posibila răspândire a infecției sau contaminării”. Având în vedere trimiterea la sintagma „,spații special amenajate”, rezultă că situația premisă a infracțiunii nu privește și măsura izolării la domiciliu a persoanelor. De remarcat este că definiția dată noțiunii de carantină de art. 352, alin. 9 C.pen. intră în contradicție cu definiția dată de art. 1 din Ordinul nr. 414/2020 privind instituirea măsurii de carantină pentru persoanele aflate în situația de urgență de sănătate publică internaţională determinată de infecția cu COVID19 și stabilirea unor măsuri în vederea prevenirii și limitării efectelor epidemiei ${ }^{3}$ : ,in ințelesul prezentului ordin, prin carantină se înțelege atât instituirea măsurii de carantină instituționalizată (în spații special amenajate), cât și instituirea măsurii de izolare la domiciliu”.

Observăm, astfel, că fapta persoanei de a părăsi starea de izolare la domiciliu nu este incriminată în măsura în care nu a condus în mod efectiv la răspândirea bolii - situație în care fapta se va putea încadra în prevederile art. 352, alin. 2 C.pen. Mai constatăm că legiuitorul pedepsește mai ușor fapta unei persoane cu o suspiciune ridicată de a fi infectată și aflată în carantină de a părăsi această stare, dar care are șansa de a nu transmite boala către alte persoane, decât fapta unei persoane aflată în izolare la domiciliu, asimptomatică, cu șanse foarte mici să fi fost infectată, care părăsește domiciliul răspândind astfel boala. Nu înţelegem această diferenţă de tratament penal în favoarea celui aflat în carantină (chiar și în condițile în care este o infracțiune de pericol), având în vedere că economia tuturor reglementărilor în domeniul sănătății publice conduce la concluzia că instituirea unei măsuri de carantină denotă o stare de o periculozitate mult ridicată faţă de instituirea unei măsuri de izolare la domiciliu. ${ }^{4}$

În ceea ce privește noțiunea de spitalizare, constatăm că nu este oferită o definiție. În doctrina foarte recentă s-a opinat deja că ,deși Ordinul nr. 414/2020 nu prevede o definiție a măsurilor de spitalizare, înțelesul acestei noțiuni este previzibil și se referă în principal la respectarea perioadei de internare și a indicațiilor medicului curant în legătură cu diagnosticarea, tratamentul medical, ingrijirea și recuperarea persoanelor infectate sau suspecte de infectare." ${ }^{\circ} \mathrm{Ne}$ exprimăm rezerve

\footnotetext{
${ }^{3}$ Publicat în M.Of. nr. 212 din 16 martie 2020.

${ }^{4}$ La data și ora redactării acestui articol, de exemplu, în România, 25.379 de persoane se află în carantină instituționalizată (echivalentul noțiunii de carantină din art. 352 C.pen.) și 91.369 de persoane se află în izolare la domiciliu.

${ }^{5}$ G.A. Lazăr, Modificările propuse pentru modificarea Codului Penal în vederea combaterii răspândirii coronavirusului, publicat în secțiunea Forum Juridic pe site-ul Facultății de Drept, Universitatea din București, la adresa: https://drept.unibuc.ro/dyn_img/aubd/Modifica\%CC\%86rile\%20aduse\%20Codului\%20Penal\%20prin\%200rdonant \%CC\%A6a\%20de\%20Urgent\%CC\%A6a\%CC\%86.pdf
} 
în legătură cu înțelesul „,previzibil” al acestei noțiuni în lipsa unei definiții legale. Mai apoi, ne exprimăm rezerve și mai puternice în legătură cu suficiența incriminării prin referirea numai la spitalizare.

Din păcate, la acest moment ne putem deja imagina scenariul în care capacitatea sistemului sanitar ar fi depășită. La acel moment, cum se întâmplă deja în contextul prezentei pandemii în alte state, ${ }^{6}$ numai cazurile grave ar fi tratate prin spitalizare. Cazurile ușoare sau asimptomatice ar fi tratate „la domiciliu”. Așadar, asemenea situații nu se vor încadra nici în noțiunea de carantină, nefiind vorba despre „spații special amenajate”, nici în noțiunea de spitalizare. Pe cale de consecință, deși din punctul de vedere al răspândirii unui virus (în situația prezentă, a coronavirusului), există aparent aceeași periculozitate a deplasării libere a unui cetățean aflat într-o stare medicală gravă (internat într-un spital) ca și a deplasării unui cetățean asimptomatic (infectat, dar tratat la domiciliu), fapta lipsită de urmări a primului va fi incriminată, pe când fapta lipsită de urmări a celui de-al doilea nu va fi incriminată. Este evident că fapta celui din urmă nu va putea fi încadrată în dispozițiile alin. 2, text ce prevede un rezultat ca urmare imediată. Așadar, diferența de tratament între persoanele potențial infectate spitalizate și cele cert infectate, dar nespitalizate, apare ca fiind nejustificată.

O a doua problemă a variantei tip a infracțiunii apare în legătură cu subiectul activ. Ne întrebăm dacă cerința existenței unei situații premisă reclamă și un subiect activ calificat în persoana celui/celei supus(ă) măsurii de carantină sau spitalizare? La o primă vedere ar părea ca da.

Totuși, ne întrebăm dacă nu s-ar încadra în textul incriminator și următoarea situație: X este supus unei măsuri de carantină pe care el, personal, o respectă, nepărăsind spațiul special amenajat în acest sens. Y, apropiat al lui X, făcându-i-se dor de X, pătrunde noaptea, pe fereastră, în spațiul de carantină pentru a fi cu X, a-i duce mâncare, a povesti cu acesta etc. Y nu este o persoană supusă măsurii de carantină. Însă, din punctul nostru de vedere, $Y$ este o persoană care nu a respectat măsura de carantină dispusă pentru prevenirea sau combaterea bolilor infectocontagioase. Desigur, dacă Y s-ar infecta și ulterior ar răspândi boala, nu ar fi necesară extinderea subiectului activ al variantei tip dincolo de persoanele supuse carantinei sau spitalizării pentru că $Y$ ar răspunde conform dispozițiilor art. 352, alin. 2 C.pen. Însă, dacă Y are șansa de a nu răspândi boala, apreciem, totuși, că fapta sa nu este cu nimic mai puțin gravă decât cea a lui X care ar părăsi starea de carantină sau spitalizare. Având în vedere că art. 352, alin. 1 C.pen. nu limitează explicit sfera subiectului activ la persoanele supuse direct măsurilor de carantină și spitalizare și constatând că asemenea măsuri pot fi încălcate, nerespectate și de alte persoane, apreciem că, de fapt, subiectul activ al infracțiunii, în varianta tip, este necircumstanțiat.

${ }^{6}$ De exemplu, în Italia și Spania. 
2. Art. 352, alin. 2 C.pen. - variantă agravată sau variantă tip alternativă? (,nerespectarea măsurilor privitoare la prevenirea sau combaterea bolilor infectocontagioase, dacă fapta a avut ca urmare răspândirea unei asemenea boli”).

Actualul alin. 2 al art. 352 C.pen. preia conținutul fostului alin. 1 al art. 352 C.pen. Întrebarea care se naște este dacă fosta variantă tip a infracțiuni devine astfel variantă agravată sau rămâne o variantă tip alternativă (specială). Credem că răspunsul este unul mixt.

În primul rând, constatăm că, în cazul acestei variante a infracțiunii nu mai există niciun dubiu în legătură cu o eventuală calificare a subiectului activ: acesta este necircumstanțiat. În al doilea rând, sub aspectul elementului material, observăm o mai mare ,generozitate” a legiuitorului, referinduse la orice măsuri privitoare la prevenirea sau combaterea bolilor infectocontagioase. Totuși, diferența de esență față de varianta prevăzută la alin. 1 este reprezentată de urmarea imediată. În cazul alin. 2, este vorba despre o infracțiune de rezultat, fiind necesară răspândirea bolii ca urmare a nerespectării măsurilor de prevenire sau combatere.

Revenind la caracterizarea teoretică a variantei, apreciem că, dintr-o perspectivă, aceasta este o variantă agravată a alin. 1. Astfel, între măsurile privitoare la prevenire sau combatere se află și măsurile de carantină și spitalizare. Dacă nerespectarea acestora din urmă nu numai că generează o stare de pericol abstract, ci conduc în mod efectiv la răspândirea bolii, fapta se va încadra în dispozițiile alin. 2, atrăgând o răspundere penală mai ridicată decât cea aferentă alin. 1 .

Dintr-o altă perspectivă, alin. 2 prevede o variantă tip alternativă a infracțiunii. Dacă măsurile nerespectate nu sunt nici cele de carantină, nici cele de spitalizare, ci alt tip de măsuri instituite în mod specific pentru prevenirea sau combaterea răspândirii unei boli infectocontagioase, fapta va fi infracțiune numai dacă va conduce la o asemenea răspândire. Exemple de astfel de măsuri sunt cele cuprinse, în cazul prezentei pandemii, în Ordonanţele militare emise pe durata stării de urgență.

3. Art. 352, alin. 2 C.pen. - analiză a unor elemente de tipicitate prin comparație cu art. 352, alin. 3 C.pen. (,transmiterea, prin orice mijloace, a unei boli infectocontagioase de către o persoană care știe că suferă de această boală") și cu art. 352, alin. 4 C.pen. (,fapta prevăzută în alin. 2 este săvârșită din culpă").

Elementele de tipicitate ce nasc principalele discuții în privința acestei variante a infracțiunii sunt urmarea imediată și latura subiectivă. În mod neobișnuit, le vom discuta împreună, în mod intercalat, având în vedere că cele două elemente se află într-o relație indisolubilă, cu atât mai mult în contextul problemelor de interpretare generate de textul art. 352 C.pen. 
La o primă citire a textului de lege, pare că forma de vinovăție avută în vedere de legiuitor este intenția depășită. Această concluzie rezultă mai ales din sintagma folosită: ,dacă fapta a avut ca urmare". Constatăm că legiuitorul a folosit exact aceeași expresie folosită în cazul infracțiunilor de loviri sau vătămări cauzatoare de moarte, viol urmat de moartea victimei, agresiune sexuală urmată de moartea victimei, tâlhărie urmată de moartea victimei etc., cunoscut fiind faptul că în cazul acestor infracțiuni forma de vinovăție este intenția depăşită. ${ }^{7}$

Totuși, în cazul acestei infracțiunii de zădărnicire a combaterii bolilor, în varianta de la alin. 2, se constată, la o analiză mai atentă, o caracteristică stranie. Se cunoaște faptul că intenția depășită este forma de vinovăție specifică infracțiunilor ce presupun două rezultate, al doilea, cel mai grav, fiind datorat culpei făptuitorului. ${ }^{8}$ Or, în cazul tuturor celorlalte infracțiuni preterintenționate, sunt evidente cele două rezultate. De asemenea, în toate cazurile și rezultatul mai puțin grav este specific unei infracțiuni (loviri sau alte violențe, viol sau tentativă la viol, tâlhărie sau tentativă la tâlhărie). În cazul de faţă, dacă acceptăm intenția depășită ca manifestare a laturii subiective, suntem nevoiți să o acceptăm într-o structură în care prima urmare, cea intenționată, nu va consta decât într-o stare de pericol, iar urmarea mai gravă, datorată culpei, să constea într-un rezultat, răspândirea bolii. Aceasta nu ar reprezenta neapărat o problemă în cazul în care măsurile nerespectate sunt cele de carantină sau spitalizare. În cazul acestora, nerespectarea urmată de crearea stării de pericol este deja incriminată în alin. 1. Urmarea mai gravă constând în răspândirea bolii ar fi pedepsită, în baza culpei, ca formă de vinovăție, în alin 2.

Mai ciudată apare ca fiind recunoașterea intenției depășite în cazul nerespectării altor măsuri, neavute în vedere de varianta tip. În cazul acesta, nerespectarea măsurii de prevenire sau combatere, în sine, nu are relevanță penală dacă nu este urmată de răspândirea bolii. Evident că o asemenea nerespectare conține în mod inerent un potențial de generare a unui pericol, însă legiuitorul nu a înțeles să îi acorde relevanță penală. Așadar, în această ipoteză, dacă vom accepta intenția depășită, ar însemna să acceptăm că dintre cele două urmări specifice acestei forme a vinovăției, prima urmare este una fără relevanță penală, doar a doua urmare, cea datorată culpei, urmând să aibă o asemenea relevanță.

Acesta este momentul oportun pentru a analiza legătura cu urmarea imediată (mai gravă) a infracțiunii, respectiv răspândirea bolii infectocontagioase, urmând să revenim la discutarea laturii subiective. În esență, considerăm că legiuitorul nu a folosit cea mai fericită exprimare, aceasta având potențial generator de confuzii. Conform alin. 2 al art. 352 C.pen., urmarea imediată este reprezentată de „răspândirea bolii”. Poate că această noțiune ar fi fost mai clară și mai ușor de

\footnotetext{
7 În acest sens, V. Cioclei, Drept penal. Partea specială I. Infracțiuni contra persoanei și infracțiuni contra patrimoniului, ediția a 3-a, edit. C.H.Beck, București.

8 În acest sens, C. Mitrache, Cr. Mitrache, Drept penal român. Partea generală, ediția a 3-a, edit. Universul Juridic, București, pag. 143-144.
} 
înțeles dacă nu ar fi existat și alin. 3 al art. 352 C.pen. Or, existența acestei variante naște unele întrebări importante.

Elementul material al variantei prevăzute la alin. 3 este reprezentat de ,transmiterea bolii”. Se poate afirma că ne aflăm într-o situație în care (similar, de exemplu, infracțiunii de distrugere), legiuitorul desemnează prin aceeași noțiune atât elementul material, cât și urmarea imediată. Astfel, și urmarea imediată a variantei prevăzute la alin. 3 este reprezentată de transmiterea bolii unei alte persoane/unor alte persoane. Într-o exprimare alternativă, urmarea imediată este reprezentată de infectarea unei alte persoane/unor alte persoane.

Se naște întrebarea: sintagma „răspândirea bolii” este sinonimă cu sintagma „transmiterea bolii”? Pentru conturarea elementelor de tipicitate a variantei de la alin. 3 este necesar să se dovedească faptul că X a avut o conduită prin care a transmis boala unei anumite persoane (unor anumite persoane) şi aceasta din urmă s-a infectat ca urmare a conduitei lui X. Cu alte cuvinte, trebuie să se probeze rezultatul concret al infectării unei alte persoane, aflat în legătură de cauzalitate cu conduita făptuitorului. Pentru a se realiza urmarea imediată a variantei de la alin. 2, este necesar același demers? Este necesar să se probeze că o conduită a făptuitorului de nerespectare a unor măsuri de prevenire sau combatere a condus, printr-o legătură de cauzalitate existentă, la infectarea unei anumite persoane/unor anumite persoane?

De exemplu, într-o localitate nu există niciun caz de infectare cu coronavirus. O persoană, încălcând măsurile de prevenire și combatere, organizează un eveniment la care iau parte câteva mii de persoane (de exemplu, un meci de fotbal). Ulterior acelui eveniment, în acea localitate apar cazuri de infectare cu coronavirus. Totuși, nu se poate stabili cu certitudine că o persoană prezentă la acel eveniment, fiind infectată, a transmis virusul altor participanţi, fiind, de asemenea, posibil ca eventualii participanţi infectați să fi fost infectaţi într-o altă împrejurare. Este evident că evenimentul respectiv a prezentat un risc foarte mare și că ar fi putut conduce la transmiterea bolii către mai multe persoane. Dar se poate afirma că, în lipsa dovedirii infectării, cu ocazia acelui eveniment, a unor persoane determinate, s-a realizat urmarea imediată, constând în ,răspândirea bolii"?

Având în vedere că legiuitorul folosește termeni diferiți în alin. 2 și alin. 3, precum și luând în considerare sensul mai degrabă neindividualizat al noțiunii de „răspândire”, ar părea că înțelesul trebuie să fie diferit. Respectiv, pare, la o primă vedere, că noțiunea de răspândire nu presupune dovada infectării unei anumite persoane, în concret, ca un efect al nerespectării măsurilor de prevenire și combatere. Însă, dacă nu înseamnă „,infectare a unei alte persoane/unor alte persoane”, atunci ce înseamnă? Oare, dacă ținem la caracterizarea variantei de la alin. 2 ca fiind o infracțiune de rezultat, în lipsa dovedirii infectării unei alte persoane, care este acel rezultat incriminat, rezultat care, nota bene, trebuie să se afle într-o legătură de cauzalitate cu nerespectarea măsurilor de prevenire și combatere? 
Am ridicat recent această problemă într-o discuție purtată în cadru științific ${ }^{9}$. Opinia exprimată de interlocutor a fost în sensul că noțiunile de ,răspândire” și „,transmitere” nu sunt sinonime. S-a arătat că prima nu presupune o infectare a unei anumite persoane, în mod concret, determinat. Un exemplu ce ne-a fost oferit ar fi al unei alte pandemii, cu un virus care s-ar putea transmite și prin intermediul animalelor. Or, nerespectarea unor măsuri de prevenire care ar avea ca urmare infectarea animalelor ar realiza conținutul variantei de la alin. 2 al art. 352 C.pen., pe când, pentru realizarea variantei de la alin. 3, ar fi necesară transmiterea virusului unei alte persoane.

Avem rezerve atât în privința tezei teoretice, cât și în privința exemplului dat. Vom începe cu exemplul.

Credem că noțiunea de răspândire a bolii presupune răspândirea acesteia la oameni. De exemplu, dacă ar apărea un nou virus care nu ar fi purtat încă de nicio ființa umană, dar, ca urmare a nerespectării unor măsuri de prevedere, ar fi răspândit la un număr mare de animale, persoana care nu a respectat măsurile, la acest moment, nu a săvârșit încă o faptă tipică. Indiferent câte animale ar fi infectate, cât timp virusul nu a fost transmis omului, nu avem o ,răspândire a bolii”.

Pe de altă parte, să luăm exemplul unui virus care există deja în comunitate (pe tiparul coronavirusului) și care ar putea fi transmis la animale de companie şi de la animale de companie la oameni. Dacă X dorește să îl infecteze pe $Y$, o poate face în două moduri: direct, sau prin intermediul animalului de companie al lui Y. Dacă X transmite boala infectocontagioasă câinelui lui $\mathrm{Y}$, iar câinele, mai departe, o transmite lui $\mathrm{Y}$, în măsura în care $\mathrm{X}$ a urmărit acest rezultat, credem că nu există niciun dubiu asupra încadrării faptei în dispozițiile art. 352, alin. 3 C.pen., cu atât mai mult cu cât, elementul material al acestei variante poate fi realizat ,prin orice mijloace”. Vedem, astfel, că tipicitatea variantei de la alin. 3 se poate realiza și prin intermediul animalelor.

Concluzionând, credem că urmarea imediată constând în ,„ăspândirea bolii”, în ciuda tehnicii legislative deficitare, presupune infectarea unei alte persoane/unor alte persoane, ca urmare a nerespectării măsurilor de prevenire și combatere. Este necesar să se probeze acest rezultat, precum și legătura de cauzalitate între nerespectarea măsurilor și infectarea acelei alte persoane/acelor alte persoane.

În aceste condiții, respectiv constatând că urmarea imediată este similară în cazul alin. 2 și alin. 3 din art. 352 C.pen., care mai sunt diferențele între cele două variante? Instinctul ne-ar conduce spre latura subiectivă. Este evident că varianta de la alin. 3 se comite cu intenție directă sau indirectă. Am arătat deja, mai sus, că varianta de la alin. 2 pare că se comite cu intenție depășită, luând în considerare formularea legiuitorului.

\footnotetext{
9 În cadrul conferinței „Urgența în drept”, organizată de Facultatea de Drept a Universității din București, cu ocazia prezentării susținută de dl. drd. George-Alexandru Lazăr.
} 
În doctrina recentă s-au formulat deja două opinii în legătură cu forma de vinovăţie cu care se comite varianta de la alin. 2. Într-o opinie ${ }^{10} \mathrm{~s}$-a arătat că fapta incriminată la art. 352, alin. 2 C.pen. se comite cu intenție depășită. În aceeași opinie se subliniază în mod întemeiat mai multe probleme de interpretare și aplicare a textului de lege, arătându-se inclusiv că, nu dincolo de critică, pe calea unei argumentări a fortiori am putea să admitem pe lângă intenția depășită și intenția ca formă de vinovăţie pentru varianta prevăzută la alin. 2. Într-o altă opinie, ${ }^{11}$ combătându-se perspectiva anterior citată se arată: „Nu putem fi de acord cu opinia exprimată in doctrină în sensul că fapta incriminată la alin. (2) al art. 352 C.p. este praeterintenționată. Urmarea impusă de textul de lege, a răspândirii bolii, nu este, în opinia noastră, o urmare mai gravă, din culpă, ci reprezintă urmarea firească a infectării unei persoane. Faptul că în acest caz se poate ajunge la o suprapunere între alin. (2) și (3) nu este de natură a schimba această concluzie, deoarece alin. (3) cuprinde suficiente diferențe pentru a justifica o aplicare distinctă, fără a îngloba conținutul alin. (2). Altfel spus, transmiterea bolii se poate realiza și fără nerespectarea măsurilor de prevenire și combatere a bolii, pentru multe dintre bolile infectocontagioase astfel de norme nefiind adoptate. Din nou, considerăm esențial a analiza norma și în afara contextului prezentei pandemii."

Cum am arătat mai sus, este neuzuală tehnica legiuitorului de a crea o infracțiune preterintenționată care are în structură ca „rezultat” mai puțin grav o stare de pericol. Din acest punct de vedere, opinia potrivit căreia forma de vinovăție este intenția și pentru alin. 2 ar putea să pară întemeiată. Însă, după cum vom vedea mai jos, în opinia noastră, majoritatea argumentelor conduc spre forma de vinovăție a intenției depășite în cazul alin. 2.

Un indiciu în privința determinării laturii subiective a variantei de la alin. 2 credem că ne este oferit de alin. 4 al art. 352 C.pen. Potrivit acestuia se incriminează „fapta prevăzută în alin. 2" dacă este săvârșită din culpă. Exprimarea legiuitorului poate avea două sensuri: fie se referă la situația în care fapta este săvârșită din culpă, respectiv nerespectarea măsurilor de prevenire și combatere, fie, având în vedere dispozițiile generale ale art. 16 C.pen., de fapt, se referă la rezultat, acesta fiind imputabil pe baza culpei.

- Dacă legiuitorul se referă la faptă, la actus reus, atunci alin. 4 incriminează nerespectarea din culpă a măsurilor de prevenire și combatere, această nerespectare având ca urmare

\footnotetext{
${ }_{10}$ R. Slăvoiu, Modificarea dispozițiilor art. 352 Cod penal prin O.U.G. nr. 28/2020. Sau, de ce este periculoasă supranormarea, publicat pe www.juridice.ro, la 23.03.2020.

${ }^{11}$ G.A. Lazăr, $O$ necesară precizare în raport de forma de vinovăție cu care sunt săvârșite formele agravate ale infracțiunii de zădărnicire a combaterii bolilor, publicat în secțiunea Forum Juridic pe site-ul Facultății de Drept, Universitatea din București, https://drept.unibuc.ro/dyn_doc/completare\%20articol\%20drd.\%20lazar\%20v2b.pdf
} 
(evident, tot din culpă) răspândirea bolii. Dacă aceasta este interpretarea, atunci rezultă, zicem noi, că alin. 2 presupune forma de vinovăţie a intenției depășite.

Motivul este acela că, dacă alin. 4 prevede forma culpei iar alin. 2 s-ar referi la forma intenției, ar rămâne neacoperită de dispozițiile legale ipoteza intermediară, a preterintenției, respectiv situația în care făptuitorul încalcă intenționat măsurile de prevenire și combatere, dar răspândirea bolii are loc din culpa sa. De exemplu, dacă X, persoană neinfectată, dar care are obligații prin raportare la măsuri de prevenire și combatere, nu le respectă pe acestea din culpă, producându-se și răspândirea bolii, acesta răspunde potrivit alin. 4. Dacă același X nu respectă în mod intenționat măsurile și acceptă sau urmărește răspândirea bolii, acesta răspunde potrivit alin. 2. În schimb, dacă nu acceptăm preterintenția ca formă de vinovăție pentru alin. 2, iar X nu respectă intenționat măsurile de prevenire și combatere, dar nu prevede sau, deși prevede, nu acceptă urmarea răspândirii bolii, fapta lui nu se încadrează la niciuna din variantele prevăzute de art. 352 C.pen. Concluzia este evident absurdă.

Și mai grav, putem lua exemplul unei persoane infectate care cunoaște că suferă de respectiva boală. Dacă X, infectat și tratat la domiciliu (aşadar neaflat în carantină sau în spitalizare) părăsește domiciliul și infectează intenționat (direct sau indirect) o altă persoană, atunci fapta sa se încadrează în dispozițiile alin. 3. Dacă X nu respectă din culpă măsurile de prevenire și combatere și se produce infectarea unei persoane, atunci răspunde în temeiul alin. 4. Însă, dacă nu acceptăm forma preterintenției la alin. 2, iar X, persoana infectată, părăsește intenționat domiciliu, dar sperând în baza unor elemente obiective (ora înaintată din noapte, lipsa oamenilor pe stradă, necesitatea unei plimbări scurte, păstrarea unei distanțe mari față de orice altă persoană etc.), totuși se produce din culpă (cu prevedere, în exemplul nostru) infectarea unei persoane, fapta sa apare ca fiind neîncadrabilă penal.

Desigur, putem argumenta că, dacă legiuitorul incriminează în alin. 4 nerespectarea din culpă a măsurilor, incriminează implicit și răspândirea din culpă a bolii, ca urmare a unei nerespectări intenționate a măsurilor de prevenire și combatere. Astfel, în cele două exemple anterioare, faptele lui X despre care am afirmat că ar fi neîncadrabile penal, ar putea fi încadrate în dispozițiile alin. 4. Însă, oare aceasta să fi fost voința legiuitorului? Să pedepsească la fel fapta de răspândire a bolii ca urmare a unei nerespectări din culpă a măsurilor și răspândirea ca urmare a unei nerespectări intenționate a măsurilor? Este acceptabilă o asemenea modalitate de interpretare? Credem, mai degrabă, că nu.

- Potrivit art. 16 C.pen., formele de vinovăţie sunt definite prin raportare la rezultat. Astfel, culpa apare atunci când făptuitorul nu prevede sau prevede, dar nu acceptă, rezultatul faptei sale. Astfel, am putea interpreta dispozițiile alin. 4 prin raportare la rezultatul constând în 
răspândirea bolii. $\mathrm{Cu}$ alte cuvinte, ar însemna că legiuitorul are în vedere în cazul variantei prevăzute la alin. 4 ipoteza în care nerespectarea măsurilor de prevenire și combatere este intenționată (conștientă, asumată etc.) iar rezultatul constând în răspândirea bolii se produce din culpă. Evident, o asemenea interpretare ar însemna, per a contrario, că varianta prevăzută în alin. 2 este una intenționată, respectiv în acea ipoteză făptuitorul urmărește sau acceptă răspândirea bolii.

Pentru a rezolva dilema anterior expusă, o soluție ar fi să verificăm sensul exprimării legiuitorului penal în alte situații în care folosește aceeași sintagmă cu cea utilizată în alin. 4 al art. 352 C.pen. De exemplu, expresia „fapta este săvârşită din culpă” este folosită în art. 196, prin referire la art. 193 și 194 C.pen. În această situație, evident, legiuitorul se referă la actus reus, respectiv la elementul material constând în lovire sau alte violențe, chiar acesta fiind imputabil pe baza formei de vinovăție a culpei, iar nu doar rezultatul constând în suferința fizică sau urmările progresive ulterioare. O interpretare similară întâlnim în cazul art. 202, alin. 5 C.pen., art. 286, alin. 4 C.pen., art. 345 , alin. 5 C.pen. etc.

Rezultă, astfel, că dintre cele două posibilităţi de interpretare a dispozițiilor alin. 4, prima este cea validă, respectiv legiuitorul are în vedere în această variantă situația în care chiar nerespectarea măsurilor de prevenire și combatere este comisă din culpă. Împrejurarea că forma de vinovăție se transpune asupra rezultatului care se poate sau nu să se producă, respectiv răspândirea bolii, apare ipso facto. În aceste condiții, desigur, subliniem din nou faptul că dacă am interpreta textul alin. 2 în sensul că presupune forma de vinovăție a intenției directe sau indirecte, ar rămâne neacoperită de lege ipoteza în care făptuitorul acceptă sau urmărește încălcarea măsurilor de prevenire și combatere, dar nu prevede sau nu acceptă producerea rezultatului, răspândirea bolii.

Consecutive, opinia noastră este că latura subiectivă a faptei incriminate la art. 352, alin. 2 C.pen. se manifestă prin intenție depășită. Rezultă astfel că alin. 2 trimite la intenție depășită, alin. 4 la culpă și alin. 3 la intenție directă sau indirectă? Sau putem accepta în cazul alin. 2 și alte forme superioare de vinovăție?

Cunoaștem cel puțin un exemplu de infracțiune în cazul căreia (chiar în contextul unei formulări deosebit de similare a legiuitorului) latura subiectivă se manifestă atât prin intenția depășită, cât și prin intenția indirectă - vătămarea corporală, în varianta prevăzută la art. 194, alin. 1 C.pen. Așadar, a considera că în cazul alin. 2 al art. 352 fapta se poate săvârși și cu intenție (cel puțin) indirectă nu ar fi o erezie.

Pentru a elucida și această dilemă, propunem să revenim la punctul care ne-a ocazionat „excursia” către alin. 4, respectiv, dacă „,ăspândire” și „transmitere” sunt noțiuni sinonime, care mai sunt diferențele între alin. 2 și alin. 3? Constatăm o diferență la nivelul laturii subiective? 
În cazul alin. 3 al art. 352 C.pen. s-a afirmat în doctrină că fapta se săvârșește cu intenție directă sau indirectă. ${ }^{12}$ Într-adevăr, lecturând textul de lege, constatăm că legiuitorul nu impune în nicio formă ca subiectul activ să urmărească infectarea unei alte persoane, ci permite implicit ca transmiterea să se comită și cu intenție indirectă, făptuitorul acceptând faptul că acțiunea sa conduce la infectarea subiectului pasiv.

În aceste condiții, nu putem accepta în privința alin. 2 și intenția indirectă, ca formă de vinovăție. Motivul este acela că s-ar realiza, pentru anumite situații, o dublă incriminare. Astfel, X, persoană infectată care știe că este bolnav, încălcând măsuri de prevenire și combatere întreprinde acțiuni prin care acceptă că ar putea infecta alte persoane. Dacă am accepta intenția indirectă în cazul alin. 2, atunci fapta lui X s-ar încadra atât în dispozițiile alin. 2, cât și în dispozițiile alin. 3. O asemenea situație este inacceptabilă.

Din acest motiv, credem că forma de vinovăție în cazul alin. 2 este intenția depășită, iar în cazul alin. 3 este intenția directă sau indirectă.

Desigur, tehnica legislativă profund deficitară lasă cel puțin o situație gravă neacoperită de textul de lege. Așa cum s-a arătat în doctrină ${ }^{13}$, dacă X are simptome, dar nu îi este confirmată încă boala, așadar nu știe că este bolnav, ci doar bănuiește, și întreprinde acțiuni (care nu reprezintă încălcări ale măsurilor de carantină sau spitalizare) prin care acceptă sau urmărește ca, dacă este bolnav, să transmită boala unei alte persoane, este imposibil de încadrat fapta în oricare dintre variantele art. 352 C.pen. Suntem de acord cu autorul citat în privința dificultății înfățișate de acest exemplu. Credem însă, cu fermitate, că nu se cuvine nicio interpretare in extenso a normelor incriminatorii numai pentru a asigura incriminarea faptei anterior expusă.

Cum am arătat mai sus, într-o opinie exprimată ${ }^{14} \mathrm{~s}$-a arătat că alin. 2 ar impune forma de vinovăţie a intenției, rămânând suficiente alte elemente de diferențiere a celor două variante. Se arată, de exemplu, că varianta de la alin. 3 se poate comite și fără nerespectarea măsurilor de prevenire și combatere. Aceasta nu credem că este o diferență care să justifice prin ea însăși existența ambelor variante. În primul rând, observăm că legiuitorul a precizat, cu privire la elementul material al variantei de la alin. 3, că acesta poate fi realizat prin orice mijloace, deci și prin nerespectarea măsurilor de prevenire și combatere. ${ }^{15}$ În al doilea rând, dacă aceasta ar reprezenta diferența, nu mai subzistă logica pedepselor. Ar însemna ca o faptă de infectare a unei alte persoane prin nerespectarea unor măsuri de prevenire și combatere reglementate și, pe cale de consecință,

\footnotetext{
12 R. Slăvoiu, op.cit.

13 Idem

${ }^{14}$ G.A. Lazăr, op.cit.

${ }^{15}$ R. Slăvoiu, op.cit.
} 
previzibile și obligatorii, să fie mai ușor sancționată decât fapta de infectare a unei alte persoane fără nerespectarea unor asemenea măsuri.

\section{Scurte considerații suplimentare în legătură cu alin. 3 și 4 ale art. 352 C.pen.}

Având în vedere faptul că în capitolul precedent am făcut referiri ample la aceste variante, expunând explicit și implicit concluzii privind elementele de tipicitate, nu vom relua argumentele în cuprinsul prezentului capitol.

Ne rezumăm la a puncta câteva aspecte. Constatăm, în primul rând, că în cazul alin. 3 elementul material constă în ,transmitere, prin orice mijloace, a unei boli infectocontagioase”. Urmarea imediată este reprezentată de infectarea uneia sau mai multor persoane. Subiectul activ este circumstanțiat, respectiv numai persoana care suferă de o asemenea boală și, în plus, știe acest lucru. În mod particular, dorim să subliniem că subiectul activ nu trebuie doar să ştie că suferă de o boală, ci că aceasta este infectocontagioasă. În mod evident, în privința actualei pandemii, având în vedere mediatizarea, este practic imposibil să fie identificată o persoană care să nu știe că Covid19 este o boală infectocontagioasă. De asemenea, cu siguranță în legătură cu alte boli nu se va pune această problemă. Totuși, probabil că situațiile faptice ne vor surprinde și, în legătură cu această cerință, va trebui să fie luată în discuție măsura în care un anume făptuitor a cunoscut că boala sa este, într-adevăr, infectocontagioasă. Afirmând acest lucru, avem în vedere că inclusiv știința medicală este surprinsă uneori de noi maladii.

În ceea ce privește alin. 4, subliniem forma de vinovăție, fapta fiind săvârșită numai din culpă. Am elaborat asupra modului în care trebuie să fie interpretată latura subiectivă în cuprinsul capitolului anterior.

\section{Art. 352, alin. 5-7 C.pen. - variante agravate.}

Toate aceste variante agravate au fost introduse în textul art. 352 prin O.U.G. nr. 28/2020.

Apreciem că este indubitabil că alin. 5 și 6 reclamă intenția depăşită ca formă de vinovăție. Formularea legiuitorului este practic identică cu alte situaţii în care a incriminat în variante agravate producerea urmărilor preterintenționate constând în vătămări corporale sau decese. Pe cale de consecință, dacă subiectul activ nu respectă, în mod intenționat, măsurile de carantină și spitalizare ori măsurile de prevenire și combatere sau acesta transmite intenţionat boala unei alte persoane, iar asemenea conduite produc rezultatul mai grav al vătămării corporale sau decesului subiectului pasiv, imputabil făptuitorului pe baza culpei, se vor reține, după caz, dispozițiile art. 352, alin. 5 sau 6 C.pen. 
Dacă, prin conduita sa, subiectul activ a urmărit sau acceptat producerea acestor urmări, va fi incident, în principiu, concursul de infracțiuni, din nou, după caz. De exemplu, dacă făptuitorul a transmis o boala infectocontagioasă unei persoane știind că aceasta poate produce decesul și acționând într-o stare de nepăsare faţă de posibilitatea producerii unui asemenea rezultat, se va reține un concurs de infracțiuni între art. 188 C.pen. și art. 352, alin. 3 C.pen.

Totuși, apreciem că soluția concursului trebuie nuanțată. Nu trebuie să scăpăm din vedere obiectul juridic principal al infracțiunii de zădărnicire a combaterii bolilor. Acesta trebuie să se subordoneze obiectului juridic generic al capitolului, respectiv relațiile sociale ce au în vedere protejarea sănătății publice, nu a sănătății unei anumite persoane. Să luăm în discuție un exemplu. X se află în comă izolat de orice altă persoană. Y, urmărind să îl ucidă, îi introduce în corp o substanță cu o concentrație virologică uriașă, aptă să îi producă decesul în câteva minute, rezultat care se și produce. Presupunând că nici nu există posibilitatea ca virusului să se transmită de la o persoană decedată, nu vedem niciun motiv pentru a se reține și infracțiunea prevăzută la art. 352, alin. 2 sau 3 C.pen. Într-o asemenea situație, nerespectarea măsurilor de prevenire a bolilor infectocontagioase sau transmiterea virusului către $\mathrm{X}$ nu reprezintă decât o modalitate de ucidere, neavând legătură cu obiectul juridic al infracțiunii de zădărnicire a combaterii bolilor, respectiv cu sănătatea publică.

În cazul alin. 7 al art. 352 C.pen., forma de vinovăție este, evident, culpa.

\section{Concluzii și propuneri de lege ferenda.}

Credem că multiplele neconcordanțe și neclarități evidențiate în prezentul articol, precum și altele evocate în doctrina recentă, dovedesc faptul că legiuitorul a acționat impulsiv. Reiterăm că modificări legislative erau, neîndoielnic, necesare în ceea ce privește art. 352 C.pen. Însă soluțiile legislative beneficiază de atributul întinderii în timp dincolo de momentul prezentei pandemii. Mai mult decât atât, chiar și în raport de situația prezentă, neclaritățile pot crea impedimente jurisprudențiale pentru cauze deja existente sau din viitorul apropiat.

Luând în considerare toate problemele expuse mai sus, cu permisiunea cititorului, în finalul prezentului articol, vom avea îndrăzneala de a formula o propunere de lege ferenda concretă, elaborând un potențial text viitor al art. 352 C.pen.:

1) Nerespectarea măsurilor privitoare la prevenirea sau combaterea bolilor infectocontagioase se pedepsește cu închisoare de la 6 luni la 2 ani sau cu amendă.

2) Dacă fapta prevăzută în alin. 1 a avut ca urmare transmiterea bolii infectocontagioase la una sau mai multe persoane, pedeapsa este închisoarea de la 1 la 4 ani sau cu amendă.

3) Nerespectarea măsurilor privitoare la prevenirea sau combaterea bolilor infectocontagioase, având ca urmare transmiterea bolii la una sau mai multe persoane, 
dacă făptuitorul a acceptat sau a urmărit producerea rezultatului, se pedepsește cu inchisoarea de la 2 la 5 ani.

4) Fapta prevăzută la alin. 2, săvârșită de o persoană care știe că suferă de respectiva boală infectocontagioasă, se pedepsește cu închisoarea de la 2 la 5 ani.

5) Fapta prevăzută la alin. 3, săvârșită de o persoană care știe că suferă de respectiva boală infectocontagioasă, se pedepsește cu închisoarea de la 2 la 7 ani.

6) Tentativa la infracțiunea prevăzută de alin. 5 se pedepsește.

7) Dacă faptele au avut ca urmare vătămarea corporală sau decesul uneia sau mai multor persoane, se vor aplica regulile concursului de infracțiuni, după caz.

Materialul a fost publicat în revista online a Facultăţii de Drept, $\underline{\text { AUBD - Forum Juridic nr. }}$ $\underline{1 / 2020 .}$ 